\title{
The treatment of problems of our world in the primary education. Study with teachers in initial training
}

\author{
Olga Moreno-Fernández ${ }^{1 \mathrm{a}}$ and Pilar Moreno-Crespo ${ }^{2}$ \\ ${ }^{1}$ University of Seville, Faculty of Educational Sciences, Calle Pirotecnia s/n4.89, 41013Sevilla,Spain \\ ${ }^{2}$ University of Extremadura, Teacher Training College, Avenida de las Universidades s/n, Torre \\ 2-2L, 10003Cáceres, Spain
}

\begin{abstract}
The pace of change in our world poses to school a new way to address the problems of our world. This research pretend to deepen in the ideas that teachers in initial training have about to work socioenvironmental problems in Primary classrooms. The study was conducted in two Spanish Universities. We opted for open-ended questionnaire and data analysis with SPSS and Atlas.Ti. The data suggest that the lack of consensus between topics that are relevant and the topics which may or may not be in the stage of Primary generate controversy and debate. This leads us to reflect on the role of education today.
\end{abstract}

\section{Introduction}

In recent years the world is being immersed in a process of acceleration that results in numerous and continuous changes that are affecting all areas of life. A context social and environmental that exposes starkly how the symptoms resulting from globalization are affecting the planet, and therefore humans. The inequalities that have led to poverty thresholds are becoming more defined, unequal access to resources and the unbalanced distribution of wealth, the increasingly aggressive climate changes, or the disappearance of ecosystems that destabilize the natural systems, they have become realities impossible to deny $[8,9,18$ and 25]

With the globalization of the world, of the relationships, of the influences, the human being continues maintaining a reductionist vision that proposes answers limited and partial. Difficult answers to apply to questions as complex as the socio-environmental problematic that are giving nowadays in the world [2].

We face the dualism Nature-Society, which Descola and Palsson [4] (pp. 6-12) deconstruct arguing that "the persistence of this dualistic thinking prevents the development of a closer, comprehensive and complex understanding of reality" and that "the influence of

\footnotetext{
a Corresponding author: omoreno@us.es
} 
the social construction of Western dichotomous thinking, in which we find clear cultural examples where there is no any separation between the natural and the social, understanding them as a single element".

Therefore, we agree with Ortega Sánchez Ruiz \& Romero [21] (pp.162-163) that "we do not believe that is the most urgent continue to report on the dangers ahead for the worrying environmental degradation. Society is sufficiently informed of environmental degradation. Needs rather look the other way to nature; establish bonds of cordial relationship with her".

We found numerous scientific studies supporting education as agent performance against middle-generated environmental crisis, and that also emphasize environmental education [1,5,6,7,19 and 20]. Given the importance of educational processes generated to address the socio-environmental degradation we find that they occur before the impassivity of society in general. One of the reasons for this situation is that those affected are those in positions most defenseless, the most vulnerable groups [8,919 and 20].

We have to remember that the school educates and trains not only in relation to a series of objectives, content, or competences, but also on the acquisition of social and environmental values, which gives it a great burden of responsibility. Issues can only be addressed in educational classrooms by teachers and educational communities committed to their environment and the world in which we live. Social and environmental changes that have been impregnated with one or another way the education system and those who are trying to adapt more or less successfully [19].

It is usual the relavancia to contribute to the formation of a citizenry that reaches a majority that allows critically evaluate relevant issues that happen in the society of which they are part. We recognize that educational institutions have the responsibility to generate the vital means to try to change the situation of planetary emergency that we are doomed, and the urgency to acquire a focus on 'problems mindset' program that allows sustainable actions committed to ethical action [14,15 and 26].

The educational approach is to establish a "way of thinking problems" and give them answers as part of a broader educational perspective. This perspective is known as a methodology for research in science education [13] for investigation of the environment in general [3] or academic research[11,12,16, 22 and 23].

It is also clear that the prevailing constructivist perspective in the Spanish education system should not be the one to guide and determine the educational approach; there must be other contributions, which can not be moved without teaching, but have to be reworked from a specific educational approach. Otherwise, there is little point a constructivist, critical and complex didactic approach if teachers can not, do not know or do not want to assume from our professional approaches [10,24].

Significant, real and current problems affecting the planet and that students must be informed and trained to respond to them, addressing them from the simplest to the most complex, from the nearest to the farthest, from the local to the global.

\section{Methodology}

There has been a descriptive-interpretative research which involved 144 students who are studying the Degree of Primary Education in the Universities of Seville and Extremadura. We have opted for a qualitative methodology that allows us to study type and analyze the conceptions of the subject at hand to the teachers in initial formation interpreting their responses.

For the withdrawal of information we design a questionnaire structured in 7 opened questions. The aim of the investigation was to know the perception that the student body 
have before issues as the socio-enviromental problems current and his future work in the classrooms as teaching staff.

Data and information obtained were recorded by coding the words and expressions that show students not downplaying the numerical results. Thus, a considerable part of the information referred to in written words, especially when considering its analysis, but has also made use of quantitative analysis. For information processing two types of analyzes were conducted: through quantitative and qualitative SPSS statistical program through the Atlas. Ti program (version 6.2).

The structure followed for the study methodologically has passed the approach to research questions, selection, design of the categories and subcategories; development, validation and application of the questionnaire; analysis of data collected with this instrument; discussion of the results and drawing conclusions. In this paper, we focus on qualitative data while relying on quantitative data.

\section{Research Results}

From the results we can say that the teachers on initial training recognize the socioenvironmental problems that are currently taking place in the world but at different levels.

Thus, $3 \%$ said not recognize, while 5\% say they find it hard to recognize. Thoroughly analyzed those responses that refer to the recognition of the socio-environmental problems that are currently taking place in the world (a total of 93\%), distinguished 30\% not falling in detail and make reference to issues such as Media communication or the impact that man has on the environment without giving examples without giving details of how to understand them. On the other hand, $13 \%$ of cases end segmenting in one area; ie, affecting the social plane on the environmental plane.

However, most respondents (40\%) recognize a basic level, being able to give examples, as extracted from the following excerpts: TFI-UEX28: "Yes I recognize, and understand how conflicts aimed at changing society. Therefore, it is necessary to know them and treat them to know what is happening around us and its consequences".

At the highest level categorization is $9 \%$ of the sample. They are the ones who go a step further and reference to the need to intervene to protect the planet: The extracted database revealed that although most of the teacher a ininitial training recognizes the social and environmental issues that are occurring in the world, to analyze the data is still there remains a strong separation between the social and the environmental. Therefore we believe that inherited the classical view in which the world is divided between the social / environmental and the human / nature.

For that reason it is necessary to overcome this compartmentalization of knowledge that end moving to the realm of cotidianoen for an integrated and systemic approach that addresses the events that occur on the planet from a local approach to global, in what has become known "glocal".

Among the topics that teachers in initial training deemed necessary work in the classroom are differences between universities. The students of the University of Seville refer to issues such as racism, poverty, over-consumption, pollution, Ebola, crisis or evictions, among others. Topics that are not in the habit of being present in the educational traditional curriculum and that nevertheless they are of current importance, occupying of important form the diverse mass media.

While the students of the University of Extremadura focuses more on the transverse axes (environmental education, health education, sex education, etc ...) that although contemplated within the educational curriculum end up not being visible in many cases.

From the data extracted topics most frequently mentioned by university students refer to Ebola, environmental issues such as pollution or recycling, wars (especially referred to the 
conflict in the Gaza Strip), education for health, bullying, new technologies, poverty, evictions or crisis. Current issues are constantly present in the media and, to a greater or lesser extent, affect the country in which they live. While the need to incorporate them into the curriculum for primary education seems to be an underlying concern among teachers in initial formation, different levels of commitment are detected.

In this sense, only $1 \%$ believes it is not necessary to work socio-environmental problems in educational classrooms. We note that $13 \%$ of respondents noted that not all issues are likely to be addressed: TFI-UEX12: "[...] it depends on the theme you're going to deal with the students".

The $75 \%$ refers to the need to address these issues, although stressing the need to start from the interests of students in primary, as well as its immediate context, in order to understand the world in which they live, just as you can read some examples of the data collected: TFI-US28: "[...] another problem I see is the content to be taught in classes, these should emerge after meeting the interests of the children, their important characteristics and also the interests of our society. By that I mean that it should be given much information as possible to be prepared for the society around us, the current problems we see in the news ... in my opinion ... prepare children for citizenship ".

Influencing interest to work relevant issues of social and environmental issues, referring to the need to promote sensitivity and awareness of students on the social, political, economic and environmental in which the world is living, being necessary to promote critical thinking .

Although in general we can say that the teacher in initial training recognizes the social and environmental conflicts that are currently taking place in the world, including in some cases reference to the need to incorporate into the classroom is done, when they are directly asking the question Do you consider it is necessary to work them in the classroom Primary?, the opinions begin to diversify.

The overall analysis shows that $96.5 \%$ referred to the need to address relevant social and environmental problems in the classroom. Deeply analyzed these responses can establish a number of subcategories determined by the degree of complexity in writing made by the respondents. Hence we can say that this overall percentage, only $2.8 \%$ say they are not matters to which education must respond, and $0.7 \%$ of the responses have not been categorizable.

Teachers in initial formation begin to encounter prejudices about what children of those ages know or do not know, and the feasibility of dealing with certain issues or difficulty they entail. The debate on the difficulty or impossibility of working themes that are beyond the traditional textbook or no support or justification is added normatively.

So the work from current problems, although important and necessary, as noted by a considerable majority in questions 1 and 2, it starts to dilute to the possibility of including in their teaching practices.

To the question: Do you think it is possible to include in your teaching practice as future teachers? $96.5 \%$ said avoiding entering the field, referring to the importance of work around social and environmental problems in the classroom, but without much more information.

Looking at this in more detail percentage enters assessing essential nuances. Thus, $35 \%$ think that although he believes it would be possible to include relevant topics in the classroom through their teaching practices thought to be difficult tasks because school structures that govern the system (atomized content, schedule inflexible, little consensus among teachers to work issues that are beyond the textbook, misunderstanding of families work certain issues committed...). But he believes it could be done by including them within the curriculum. We note below some of the statements that make for this purpose: 
TFI-UEX7: "[...] it depends on the political will and the members of the educational institution".

The $15.4 \%$ say it is a problem that the teaching methodology used to develop the content, referring to the need to rotate from a traditional methodology where students of primary education is a mere receiver of content to a more active approach and participatory, to incorporate small research, debates, case studies that may subsequently be applied to real life, so transferring the invisible boundary that exists between the school and the neighbourhood in which they live.

Of this $96.5 \%$, only $2.1 \%$ indicated that although it considers possible meets the handicap of inexperience, which will be a progressive work to go incorporating them into the classroom slowly.

The remaining $44 \%$ refer back to the work of some specific subject, to do so without being an assessable work, work it only in the last cycle, giving little information on the issue to work or taking great care not to indoctrinate. Only $2.8 \%$ believe they do not work because they are not educational issues. $0.7 \%$ of respondents have not been categorizable because they did not answer the question.

Therefore, and at this point, we believe that this new generation of teachers becomes somewhat traditional educational model imposed in classrooms, is that, as noted by Garcia Perez \& De Alba (2008, p.4), "the traditional disciplinary organization of classroom content does not provide the treatment of the social and environmental problems of our world; on the other, working methods basically transmissive and repetitive, do not help train students in new skills that today's society demands".

A challenge for the XXI century school must respond, so it was considered elaborate on what could make school education to form citizens of this world? All respondents, one way or another, indicate the need for continuous training of teachers to offer alternatives to traditional banking school or encouraging more participatory methodologies that accommodates student voice as a top of the world living, so it is necessary for a comprehensive education that favors a rich education in values. And, although possible, it is difficult for school educated citizens of the XXI century XXI century when it has been stuck in the XIX century [9 and 17].

Although difficult, chances are reflected in the statement made by the respondent teachers in initial training, among which the incorporation of new technologies into the classroom by encouraging more enjoyable classes, the opening the school to society and the environment, students more aware of their reality and therefore more active and empowered by to intervene in society, make the participant students of the socio-environmental situation of the planet and encourage empathy.

As limitations, highlight the family ideology and the adoption center to discuss issues that deviate from the provisions of the textbooks used as benchmarks to conduct the teaching / learning.

\section{Conclusion}

The University is responsible for initial training teachers to achieve the necessary skills to enable them to acquire the tools and skills for reflection, deconstruction / construction of the professional practice as future teachers own. Investment in higher education is geared towards citizens develop skills for learning to learn, for autonomy and personal initiative and the social and civic development.

It is precisely the skills that teachers should possess and promote in its students, among others. Thus we stand in facing the educational tradition that sees the teaching profession as a transmitter mere knowledge field, which is pre-set textbooks, simplistic content and fragmented that do not lead to understanding the world in which we live of complex shape 
and, therefore, also to understand the social, environmental, cultural issues ... that are occurring in it and because of globalization change at a frantic pace.

In this sense, the research raises new questions, as we draw a scenario in which respondents have concern about social and environmental problems treated in the classroom to a stagnation that stands as the main obstacle own methodology, curriculum established, the structures of the educational centers and families. We conclude that the perception of the teacher / an in initial training on dealing with social and environmental problems in the classroom is still far from forming citizens responsible for this century.

\section{References}

1. Acebal, $\mathrm{M}^{\mathrm{a}}$. C., Formación ambiental y conciencia de maestros y maestras, Tesis Doctoral. Dirigida por el Dr. D. Vito Batista Brero Peinado, Málaga: Universidad de Málaga (2010)

2. Aledo, A. \& Domínguez, J. A., Sociología ambiental, Granada: Grupo Editorial Universitario (2001)

3. Cañal, P., Porlán, R. \& García, E., Ecología y Escuela, Barcelona: Editorial Laia (1981)

4. Déscola, P. \& Pálsson, G. (Eds), Nature and Society.Anthropological Perspectives, London: Routledge (1996)

5. Días, G. M. \& Bonotto, D. M. B., “As dimensões local e global nos entendimentos e práticas de professores participantes de um curso de formação continuada em educação ambiental", Revista Electrónica de Enseñanza de lasCiencias, 11, Vigo: Universidad de Vigo, pp. 145-163 (2012)

6. Edel, R. \& Ramírez, Ma. S., "Construyendo el significado del cuidado ambiental: un estudio de caso en Educación Secundaria", REICE. Revista electrónica Iberoamericana sobre calidad, eficacia y cambio en educación, 4 (1), Madrid: Red Iberoamericana de Investigación sobre Cambio y Eficacia Escolar, pp. 52-70 (2006)

7. Estrada, L., Concepciones sobre la educación ambiental de los docentes participantes en la red andaluza de Ecoescuelas, Tesis Doctoral, Dirigida por el Dr. D. Juan Carlos Tójar Hurtado y Dr. D. Antonio Matas Terrón, Málaga: Universidad de Málaga (2012)

8. Fernández Durán, R., "Destrucción global versus regeneración local. La necesidad de frenar y revertir el proceso incontrolado de urbanización planetaria", Artículoenlíneadisponibleenhttp: //rebelion.org/hemeroteca/ecologia/040202duran.htm, 23 de marzo de 2015 (2004)

9. García Pérez, F. F. \& De Alba, N., “¿Puede la escuela del siglo XXI educar a los ciudadanos y ciudadanas del siglo XXI?" Scripta Nova. Revista Electrónica de Geografía y Ciencias Sociales, vol. XII, $\mathrm{n}^{\circ} 270$ (122), Barcelona: Facultad de Geografia e Historia de la Universidad de Barcelona, pp. 1-15 (2008)

10. García-Pérez, F. F., "El papel de las concepciones de los alumnos en la Didáctica de las Ciencias Sociales”, Investigación en la escuela, 39, sevilla: Díada Editora, pp. 7-16 (1999).

11. García-Pérez, F. F., "Un modelo didáctico alternativo para transformar la educación: el modelo de investigación en la escuela", Scripta Nova: Revista Electrónica de Geografía y Ciencias Sociales, 4, Barcelona: Facultad de Geografía e Historia de la Universidad de Barcelona, 55-78 (2000)

12. García-Pérez, F. F., "Concepciones de los alumnos y conocimiento escolar. Un estudio en el ámbito del medio urbano", Enseñanza de las ciencias sociales: revista de investigación, 1, Barcelona: Instituto de Educación de la Universidad de Barcelona, pp. $17-26(2002)$ 
13. Gil, D., "Contribución de la historia y filosofía de las ciencias al desarrollo de un modelo de enseñanza/aprendizaje como investigación", Enseñanza de las Ciencias, 11 (2), Barcelona: Universidad autónoma de Barcelona, pp. 197-212 (1993)

14. González, Ma . C., "La educación ambiental y formación del profesorado", Revista Iberoamericana de Educación, 16, Madrid: Organización de Estados Iberoamericanos para la Educación, la Ciencia y la Cultura, OEI, pp. 13-22 (1998)

15. Gutiérrez, J., La educación ambiental: fundamentos teóricos, propuestas de transversalidad y orientaciones extracurriculares, Madrid: La Muralla (1995)

16. Merchán, F.J. \& García Pérez, F. F., "El tratamiento de problemas de nuestro mundo en la enseñanza obligatoria", Aula de innovación educativa, 61, Barcelona: Editorial Graó, pp. 9-12 (1997)

17. Monereo Font, C. \& Pozo Municio, J. I., “¿En qué siglo vive la escuela?”,Cuadernos de pedagogía, 298, Madrid: WoltersKluwer, pp.50-55 (2001)

18. Moreno-Fernández, O., Educación ambiental y educación para la ciudadanía desde una perspectiva planetaria. Estudio de experiencias educativas en Andalucía, Tesis Doctoral, Dirigida por el Dr. D. F.F. García Pérez, Mención Internacional y Premio Extraordinario, Sevilla: Universidad Pablo de Olavide (2013)

19. Moreno-Fernández, O., "Problemáticas socioambientales desde un enfoque de ciudadanía planetaria en las aulas”. Revista de Humanidades, 24, Madrid: UNED, pp. 1-17 (2015)

20. Moreno-Fernández, O. \& García Pérez, F. F., "Educar para la participación desde una perspectiva planetaria", Íber: Didáctica de las Ciencias Sociales, Geografía e Historia, 74, Barcelona: Editorial Graó, pp. 9-16 (2013)

21. Ortega Ruiz, P. \& Romero Sánchez, E., "La dimensión ética de la crisis medioambiental. Propuestas pedagógicas", Revista Teoría de la Educación, 21 (1), Salamanca: Universidad de salamanca, pp. 161-178 (2009)

22. Porlán, R., "Formación permanente del profesorado: necesidades y alternativas", Diálogos: Educación y formación de personas adultas, Vol. 3, 71-72, Barcelona: Diálogos S.L, pp. 25-32 (2012)

23. Porlán, R. \& De Alba, N., "La escuela que queremos", Investigación en la escuela, 77, Sevilla: Díada Editora,pp. 5-12 (2012)

24. Porlán, R. \& Rivero, A., El conocimiento de los profesores, Sevilla: Díada Editora (1998)

25. Riechmann, J. (Coord.), Perdurar en un planeta habitable: Ciencia, tecnología y sostenibilidad, Barcelona: Icaria (2006)

26. Vilches, A \& Gil, D., Construyamos un futuro sostenible. Diálogos de supervivencia, Madrid: OEI/cambridgeUniversityPress. (2003) 